\title{
A PERSPECTIVE ON OPEN INNOVATION IN SMALL- AND MEDIUM-SIZED ENTERPRISES IN SOUTH AFRICA, AND DESIGN REQUIREMENTS FOR AN OPEN INNOVATION APPROACH
}

\author{
W. Krause ${ }^{1} \&$ C.S.L Schutte ${ }^{2 *}$ \\ Department of Industrial Engineering \\ Stellenbosch University, South Africa \\ 116909526@sun.ac.za, ${ }^{2}$ corne@sun.ac.za
}

\begin{abstract}
This paper provides key results from an exploratory research study aimed at understanding the current landscape in small- and medium-sized enterprises (SMEs) in South Africa with regard to their appetite for, and use of, open innovation. The survey, which was conducted within a contained group of SMEs that belong to business network groups on Linkedln, explored the current use and perception of open innovation. It was found that collaboration is the approach most preferred by the SMEs surveyed, with customers and suppliers as their preferred innovation partners.
\end{abstract}

Based on the findings of the survey, this paper proposes 25 design requirements, grouped into five functional categories, for an open innovation approach. The design requirements have been developed as a primer to a more complete open innovation approach for SMEs.

\section{OPSOMMING}

Hierdie artikel bied die sleutel resultate van verkennende navorsing gerig op die begrip van die huidige landskap in Suid-Afrika ten opsigte van middelslag en klein besighede se aptyt vir en die gebruik van oop innovasie. Die opname is gedoen onder maatskappye wat deel uitmaak van 'n sake-netwerke groep op Linkedln, en ondersoek die huidige gebruik van oop innovasie, asook die beplande gebruik van oop innovasie. Samewerking is die benadering meestal verkies deur middelslag en klein besighede, met kliënte en verskaffers as die voorkeur innovasie vennote.

Die artikel stel verder ontwerpvereistes voor vir 'n oop innovasie benadering gebaseer op die bevindinge van die opname. Die ontwerpvereistes word ontwikkel ter voorbereiding vir ' $n$ meer volledige oop innovasie benadering vir middelslag en klein besighede. Vyf en twintig vereistes word in totaal groepeer in vyf funksionele kategorieë.

Author was enrolled for a PhD in the Department of Industrial Engineering, Stellenbosch University Corresponding author 
The term 'open innovation' was introduced in 2003 by Professor Henry Chesbrough of the University of California in Berkley. Chesbrough [1] defined open innovation as "a paradigm that assumes that firms can and should use external ideas as well as internal ideas, and internal and external paths to market, as the firms look to advance their technology". Since 2003 the popularity of open innovation has grown, promising to increase the effectiveness and speed of innovation. This concept was adopted mostly by larger organisations such as Phillips and Procter and Gamble, where open innovation is seen as a strategic differentiator. Some of the benefits of open innovation are bringing greater diversity into the innovation process, diversifying the risk of innovation, pooling resources, and exploiting synergies $[2,3]$.

The focus on open innovation has, however, shifted lately from larger organisations to small- and medium-sized enterprises (SMEs). SMEs are also looking to improve how they can innovate and reduce cost while reducing time to market, in order to become more competitive. In the South African context, obtaining global input into innovation processes through collaboration and open innovation can be vital to obtaining a competitive advantage. Open innovation can be considered "an important mechanism for SMEs to gain access to knowledge and technology otherwise not available within their own organisational boundaries, resulting in improved innovation performance" [4].

Open innovation can be described in the context of various theories; for example, it requires a connected network of participants (network theory) within which knowledge is created and shared (knowledge network theory) to create new value (innovation) $[4,5,6]$.

This article provides results from a survey that explored the use of open innovation within SMEs in South Africa, and that was originally presented at the CIE42 conference in Cape Town, South Africa [7]. It provides insight into the adoption of this emerging field of innovation in SMEs in South Africa, where academic research on open innovation in SMEs is usually dominated by European and American studies. The study tried to answer the questions whether South African SMEs are using open innovation in their organisations, and what preferences they have with regard to open innovation types and potential partners.

A key finding from the survey's results was that organisations are in need of a more structured approach to open innovation. This article therefore proposes several design requirements for a more structured open innovation approach.

\section{LITERATURE REVIEW}

\subsection{Innovation}

"Innovation needs to have novelty associated with it, creating something new, but also thereby generating value in the process" [7]. Innovation is understood to be the process of creating new value in the form of products, processes, services, and business models. Innovation can be a new solution to a current need, or a solution to a newly articulated or unarticulated need (e.g., the iPad).

Foss et al. [8] state that "innovative firms tend to have higher rates of profits, greater market value, better credit ratings, and stronger chances of surviving in the market". Innovation is also seen as an enabler of competitive advantage in organisations [9].

\subsection{Open innovation}

Chesbrough [1] argues that "open innovation combines internal and external ideas into architectures and systems whose requirements are defined by a business model. The 
business model utilises both external and internal ideas to create value". Enkel and Gassmann [10] reason that a company can increase its innovativeness by integrating suppliers, customers, and external knowledge sources into their own knowledge base. Open innovation includes externally-focused elements within its innovation model. In contrast, closed innovation only considers the organisation's internal capabilities to innovate.

The following diagram illustrates an open innovation model [11] whereby ideas, knowledge, and intellectual property (IP) can enter or exit the innovation funnel at any stage of the innovation lifecycle. External knowledge supplements internal capabilities to increase the speed of innovation or to provide access to knowledge not available within the organisation. The reverse is also true, where knowledge is taken outside the organisation in the form of licences, new business ventures, or products, and into new markets.

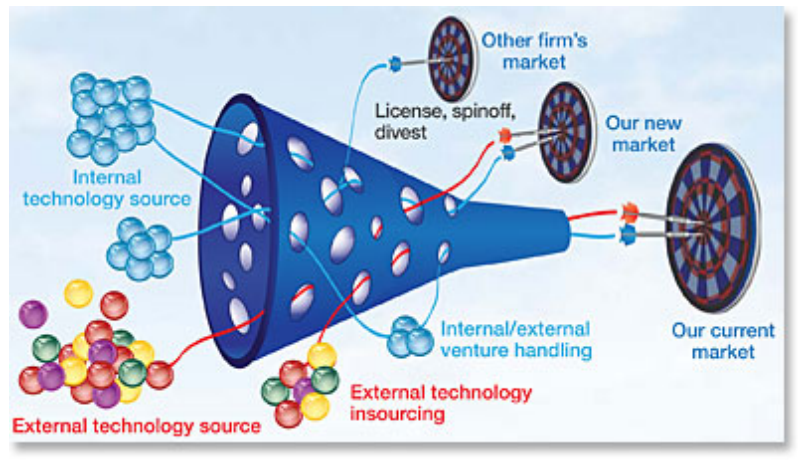

Figure 1: Open innovation

Gassmann and Enkel [12] identified three core open innovation processes:

1. Outside-in: Opening the company's innovation process to external ideas.

2. Inside-out: Taking unused IP and patents outside of the organisation so that they can be used by external parties.

3. Coupled: A combination of outside-in and inside-out processes in the form of strategic networks, joint ventures, and alliances.

Although open and closed innovation processes are defined as two separate concepts, it should be noted that the practical reality of open innovation is generally a state that lies between fully open and fully closed. Organisations can move from a state of closed innovation to a state of open innovation over time, while retaining closed innovation aspects. There will always remain parts of the innovation process that will be closed to the external environment of the organisation through patents, internal know-how, and other proprietary knowledge. 'Open' should therefore be understood as an organisation that applies open innovation concepts, together with closed innovation concepts. The level of openness may vary, however. The model in Figure 2 describes this concept further.

The model shows three layers or levels of innovation: closed, closed-open, and open. This is then mapped across the innovation lifecycle phases on a time scale. At various stages of the innovation phases the organisation can include or fluctuate between the different innovation layers.

The levels in the model can be summarised as follows:

1. Closed: No external input into the innovation phase.

2. Closed-Open: Highly controlled, limited external input into the innovation phase.

3. Open: Extensive external input into the innovation phase. 


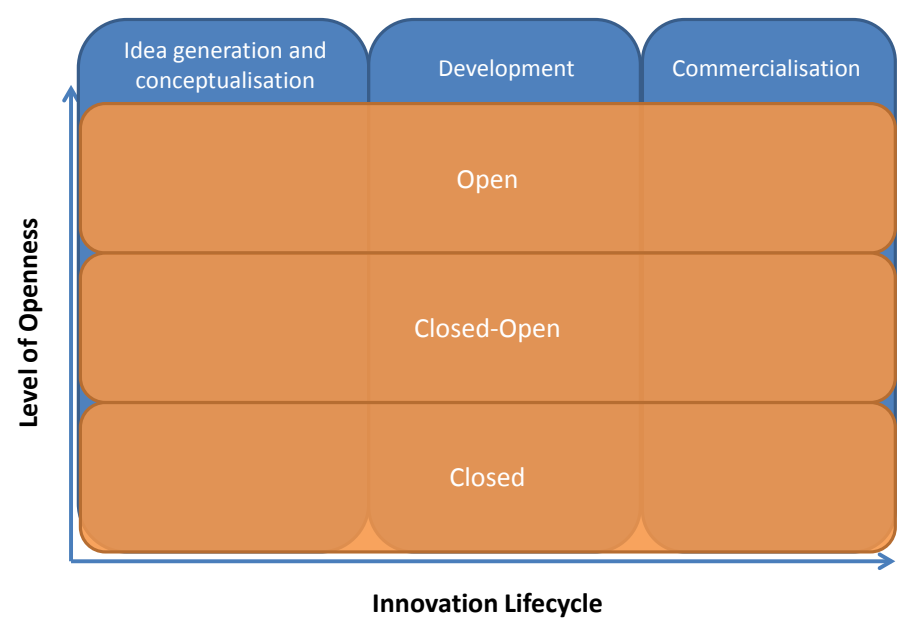

Figure 2: Level of 'openness' model

The closed-open level is introduced as a transition level between closed and open innovation. This can be where an organisation is only starting out on an open innovation journey, or where openness is much more controlled, such as in a scenario where consultants are used for expert advice in the innovation process. This will provide external input, but will normally also be controlled through strict contractual limitations, such as what information may be shared outside of the organisation's boundaries.

\subsection{Small- and medium-sized enterprises (SMEs)}

South African organisations are classified as 'small' when they have fewer than 50 employees and 'medium' when they have fewer than 200 employees (or fewer than 100 for agricultural organisations). According to Fatoki et al. [13], only 25 per cent of new SMEs created in South Africa survive the first two years of operation. As in most countries across the world, SMEs play a critical role in economic contribution and employment. SMEs are estimated to contribute 46 per cent of the total economic activity and 84 per cent of private employment [14]. Research conducted by Adcorp in 2012 [15] showed that 68 per cent of all workers in South Africa are employed by small businesses employing fewer than 50 people.

\subsection{Open innovation in SMEs}

Research into open innovation in SMEs lags behind research that involves large enterprises; this is a gap that presents a significant research opportunity $[16,17,18]$. Although more attention has been given to open innovation in SMEs over the last four years, this area still remains under-researched.

Brunswicker [19] and Bianchi et al. [17] mention some of the opportunities and challenges faced by SMEs engaging in open innovation. First, SMEs tend to have limited resources (financial, human, and physical) and fewer systematic management capabilities. Their market penetration is restricted due to the size of their organisations, while securing and enforcing IP is challenging due to the costs involved. However, SMEs have the advantage of being more flexible and having higher decision-making speeds coupled with business specialisation; this allows SMEs to benefit from open innovation, especially from an outsidein or partnering perspective.

\section{RESEARCH METHODOLOGY}

A survey was conducted among SMEs via the online professional networking platform 'Linkedln', in order to understand their appetite for and use of open innovation. Linkedln is 
considered to be a self-organising social network [20]; this supports network theory, which is considered to form part of the building blocks of open innovation [4]. The survey was sent out to 531 people from the South African groups on Linkedln shown in Figure 3.

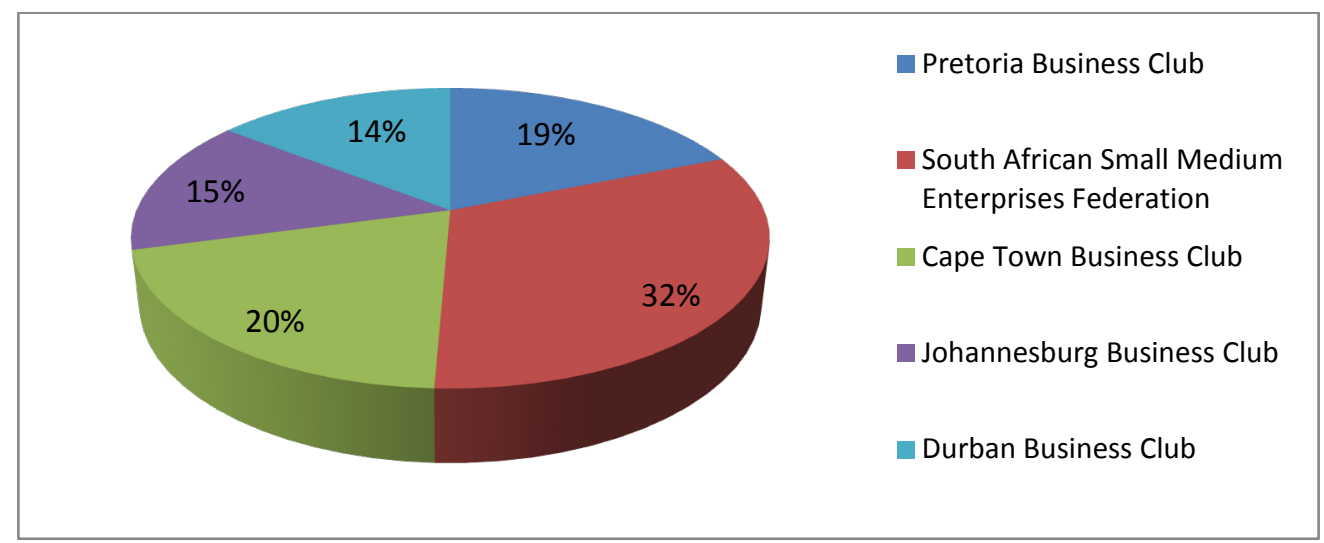

Figure 3: Survey distribution

The survey, which was conducted between March and May 2012, comprised 27 questions grouped into three sections:

1. Demographics;

2. Innovation; and

3. Open innovation

\section{RESULTS}

The following section provides key results from the survey, and the authors' interpretations of these results.

The total qualified response rate for the survey was 15.9 per cent after cleaning the data to only include responses from SMEs in South Africa.

\subsection{Demographics}

Of the responses, 52.9 per cent were received from organisations in Gauteng and 36.5 per cent from the Western Cape; this represents the economic activity distribution in South Africa. Most organisations had between 1 and 10 employees, as shown in Table 1 .

Table 1: Number of employees

\begin{tabular}{|l|c|}
\hline Number of employees & Percentage \\
\hline $1-10$ & $71.8 \%$ \\
\hline $11-25$ & $12.9 \%$ \\
\hline $26-50$ & $7.1 \%$ \\
\hline $51-100$ & $3.5 \%$ \\
\hline More than 100 & $4.7 \%$ \\
\hline
\end{tabular}

Of the responses, 77.7 per cent came from the categories of organisations shown in Table 2.

As shown in Figure 4, 77 per cent of respondents identified themselves as 'owners' of the organisation.

Most organisations that participated in the survey have established businesses. 78.8 per cent of the SMEs have been in operation for more than three years, while just over 28 per cent have been operational for 10 years or more. 
Table 2: Major organisational categories

\begin{tabular}{|l|c|}
\hline Categories of organisations & Percentage \\
\hline Information technology & 32.9 \\
\hline Educational services & 11.8 \\
\hline Professional, scientific and technical services & 10.6 \\
\hline Management of companies and enterprises & 10.6 \\
\hline Retail and wholesale trade & 5.9 \\
\hline Arts, entertainment and recreation & 5.9 \\
\hline
\end{tabular}

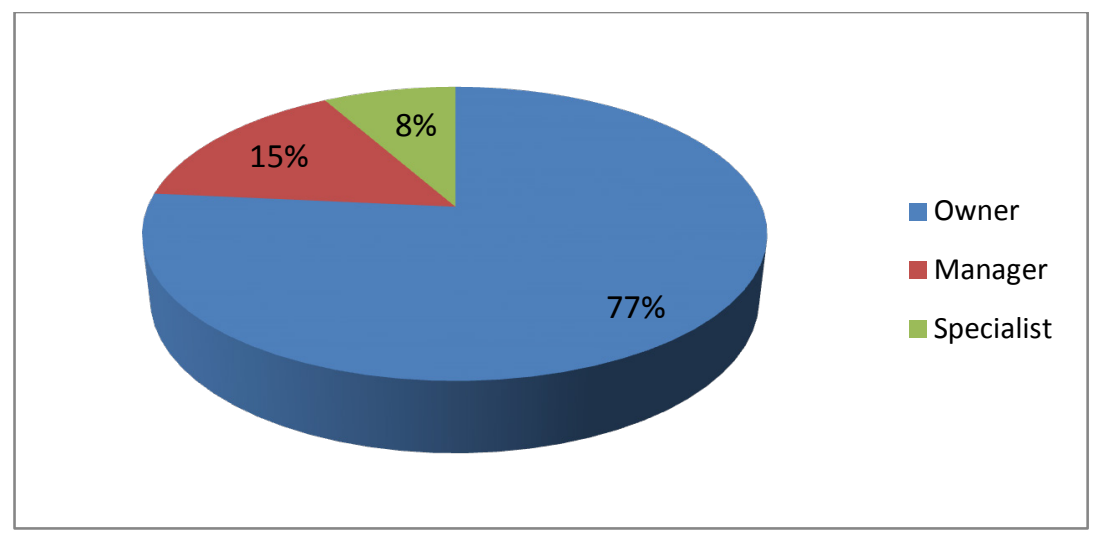

Figure 4: Roles of respondents

\subsection{Innovation}

Most respondents (61 per cent) classified their organisations as innovative. Only 18.8 per cent of respondents indicated that they have a separate budget line item for innovation, indicating an ad-hoc approach to innovation rather than a planned and structured approach. This notion is further supported by the fact that only 27.1 per cent of SMEs indicate that a formal innovation process exists. Despite this, most organisations indicated that they had deployed a high number of innovations into the market or implemented many innovations in-house in the previous year, as can be seen in Figure 5.

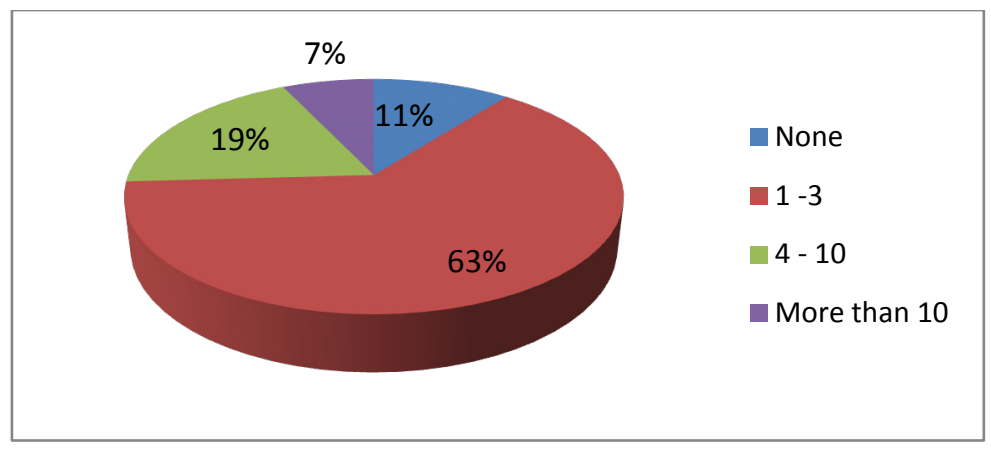

Figure 5: Number of innovations deployed

Although innovation focused mainly on products, other innovation types also received attention. 'Business model' and 'strategy' innovation scored surprisingly high, although this can be indicative of the dynamic nature of most SMEs in the market place and the need to "disrupt or (to) be disrupted" [21]. In order to stay competitive, these businesses need to be flexible and adaptive. 
Table 3: Examples of innovations implemented over the last 12 months

\begin{tabular}{|l|c|}
\hline Innovation types & Percentage \\
\hline Product & $69.40 \%$ \\
\hline Business model & $49.40 \%$ \\
\hline Strategy & $49.40 \%$ \\
\hline Process & $35.30 \%$ \\
\hline Brand and marketing & $35.30 \%$ \\
\hline Service & $29.40 \%$ \\
\hline Market and channel & $27.10 \%$ \\
\hline Customer experience & $27.10 \%$ \\
\hline None & $2.40 \%$ \\
\hline
\end{tabular}

SME respondents indicated that product innovation will remain high, with 63.5 per cent of them selecting product innovation as a focus over the next 12 months.

81.2 per cent of participants agreed with the notion that 'more than ever before, SMEs and individuals can be as innovative as large companies'. This indicates a strong belief that SMEs can compete against larger companies in the business market, as far as innovation is concerned.

\subsection{Open innovation}

Only 18 per cent of respondents agreed strongly with the statement that they considered themselves or their organisations to be knowledgeable on the topic of open innovation.

More than a third of the respondents indicated that they are not involved formally in open innovation, with 43.5 per cent indicating that they are in the early stages of roll-out and adoption. This was surprising, given the confidence level of participants about their knowledge of open innovation.

Organisations indicated collaboration as the most frequently used open innovation type, followed by customer immersion. IP or tech in-licensing or acquisition came out as the least preferred open innovation type; this indicates an opportunity for organisations to explore further this method of open innovation in South Africa.

Based on the responses to the question, "Which open innovation types will be considered in the next 18 months?", 'collaboration' was the preferred option. When applying a weighted score to the responses $(-1,1,5,9$, from highly unlikely to highly likely), 'collaboration' and 'customer immersion' again came out as the preferred options [4].

The following three areas were rated as the biggest barriers to using open innovation within SMEs:

1. Finance: Obtaining financial resources.

2. Resources: Costs of innovation, time needed, human resources needed.

3. Organisation/culture: Balancing innovation and daily tasks, communication problems, aligning partners, organisation of innovation.

The protection of IP was not rated as a significant barrier in this South African study, although this topic receives a lot of attention in the international literature [19].

Respondents were asked who they would consider to be ideal collaboration partners with whom to develop new innovations. By performing a similar weighted scoring as per the preferred innovation approaches for SMEs, the following results were obtained: 'customers', 'suppliers', 'consultants', and 'academic institutions' were rated highest; 'government development agencies' were rated as least likely collaboration partners. 


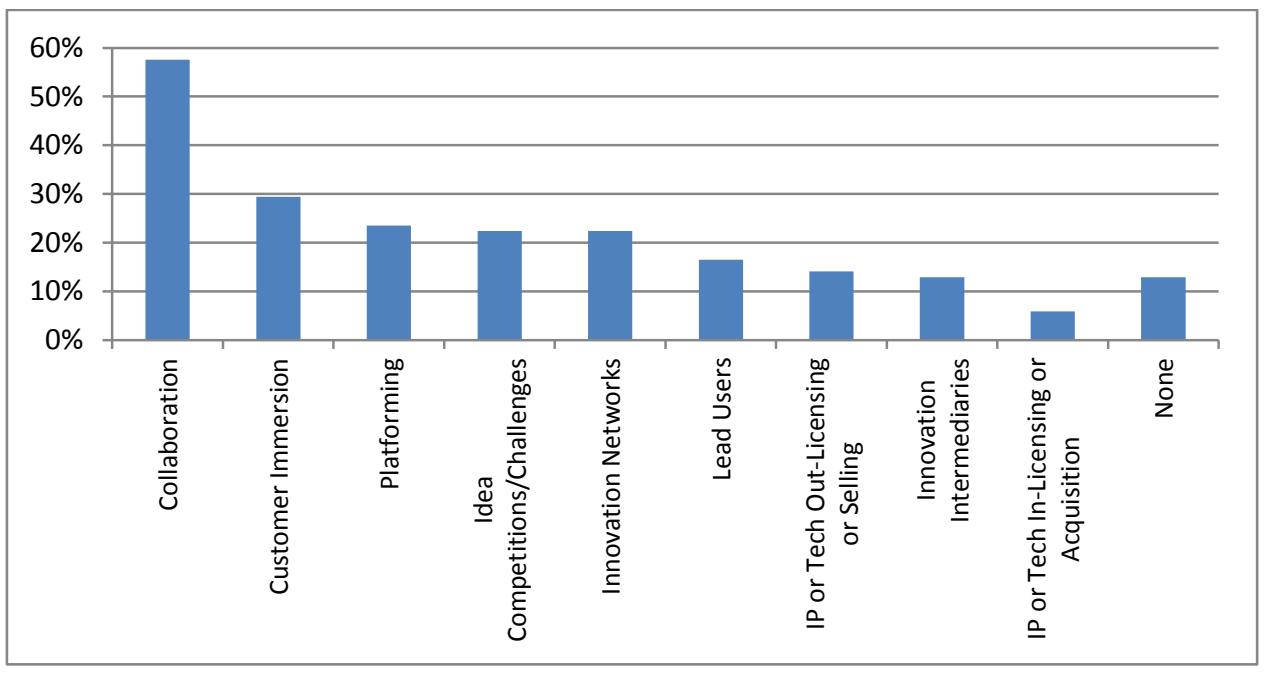

Figure 6: Open innovation types implemented over the last 18 months

Table 4: Preferred innovation approaches

\begin{tabular}{|l|c|}
\hline Preferred Innovation Approaches & Weighted Score \\
\hline Collaboration & 5.97 \\
\hline Customer immersion & 4.95 \\
\hline Platforming & 4.14 \\
\hline Innovation networks & 4.03 \\
\hline Idea competitions/challenges & 3.70 \\
\hline Lead users & 3.66 \\
\hline Innovation intermediaries & 2.58 \\
\hline IP or tech out-licensing or selling & 2.55 \\
\hline IP or tech in-licensing or acquisition & 1.56 \\
\hline
\end{tabular}

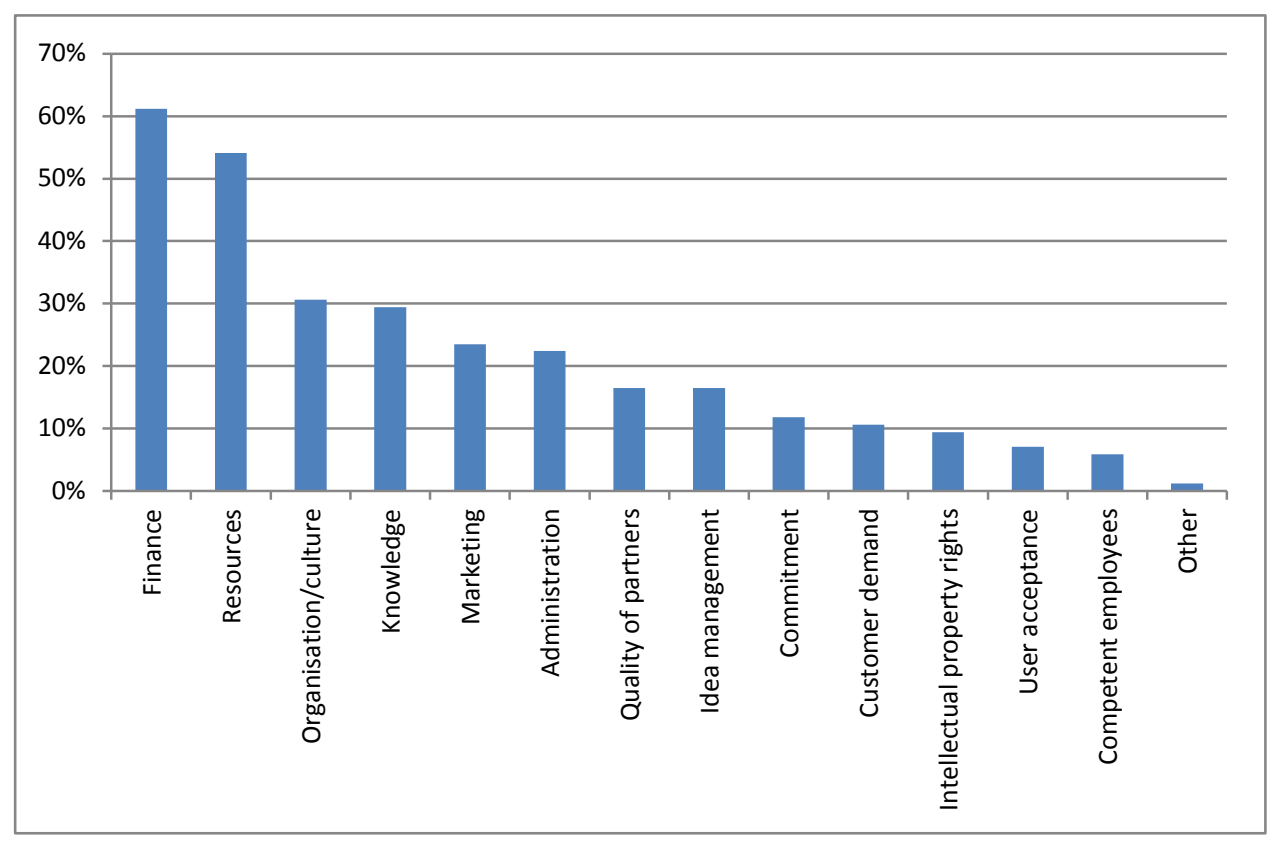

Figure 7: Barriers to open innovation 
Table 5: Preferred innovation partners

\begin{tabular}{|l|c|}
\hline Innovation partners & Weighted score \\
\hline Customers & 6.66 \\
\hline Suppliers & 5.41 \\
\hline Consultants & 4.56 \\
\hline $\begin{array}{l}\text { Universities and other academic } \\
\text { institutions }\end{array}$ & 4.38 \\
\hline Non-competitor companies & 3.93 \\
\hline Technology transfer offices & 2.58 \\
\hline Competitor companies & 2.41 \\
\hline $\begin{array}{l}\text { Government development } \\
\text { agencies }\end{array}$ & 1.67 \\
\hline
\end{tabular}

Respondents indicated that they are not confident about pursuing open innovation without assistance, even though more than 60 per cent indicated that their organisations are involved in some form of open innovation activity at present.

Table 6: Responses to "We have sufficient knowledge to pursue open innovation without assistance"

\begin{tabular}{|l|c|}
\hline Answer options & All \\
\hline Agree strongly & $9.4 \%$ \\
\hline Agree slightly & $31.8 \%$ \\
\hline Neither agree nor disagree & $30.6 \%$ \\
\hline Disagree slightly & $16.5 \%$ \\
\hline Disagree strongly & $11.8 \%$ \\
\hline
\end{tabular}

\subsection{Survey conclusion and recommendations}

The concept of open innovation as a structured innovation method is still relatively new in South Africa. The authors received feedback from participants indicating that, although they use open innovation approaches in their companies, they did not know that what they were doing was in fact open innovation. Their view on the subject was that they use these approaches because they make sense in their business context, but that they often did not make a purposeful business decision to embark on 'open innovation' as an innovation strategy.

The selection of customers and suppliers as the preferred innovation partners make sense when considering that collaboration and customer immersion were selected as the top open innovation approaches. These are also partners and approaches that are closest within the SME's network. Options outside of the immediate network, where current relationships do not already exist, would require more effort from the SME, and were thus rated lower. Of the participants, 72 per cent indicated that their companies had fewer than ten employees, which could be an indication of lower available capacity to embark on building extended relationships outside of their established network [4].

It should be acknowledged that this study might show a larger propensity towards openness for the SME participants than may be applicable for the wider South African SME population, given the participants' use of open social networks such as Linkedln. It must therefore be seen rather as a focused subset view of open innovation adoption rather than as a fully representative view of all SMEs in South Africa.

The survey results indicate that there is indeed an appetite for open innovation among South African SMEs, with a large percentage of the sample organisations starting to use this approach. Innovation typically tends to be ad hoc in nature, with no formal or structured approach. Open innovation is applied, but organisations are not confident about their knowledge of open innovation when implementing this approach. This indicates a need for a structured approach for SMEs to perform open innovation, and a need for assistance with the implementation of such an approach [7]. 
Based on the outcome of the research study, it is apparent that there is a need for a structured approach to implement and execute open innovation within SMEs. This is in line with other literature on open innovation, which states that more formal approaches to managing open innovation are required [22]. According to Chesbrough and Brunswicker [23], "a formal approach implies that firms have a clearly documented strategy for open innovation, use written and standardised processes for implementing open innovation, document their routines, and rely on different kinds of metrics for measuring and reviewing the impact of open innovation".

For developing a formal open innovation approach, the following questions must be taken into consideration:

- What are the design requirements with which the approach must comply?

- What will form the framework or boundaries for the approach?

- How will the approach detail be structured and presented?

This paper will focus on the first question, which relates to the design requirements. Before designing and developing an approach, the requirements for the design must be clearly defined. These are derived from the theoretical analysis on open innovation, findings from the open innovation survey [4,7] and the authors' experience with innovation and working with SMEs. The design requirements are also based on existing guidelines from innovation protocol development work described in the literature [24].

\subsection{Requirements categories}

Drawing on the work of Brockmöller [25], Weber [24], and Van Aaken et al. [26], the design requirements have been divided into five categories:

1. User requirements: specific requirements from the viewpoint of the user. Requirements regarding the use of the design.

2. Functional requirements: the core of the specification and in the form of performance or result demands on the protocol to be designed. What the approach is designed to do.

3. Boundary conditions: requirements or rules that have to be met unconditionally and may not be altered. E.g., legislation, ethical habits, and code of conduct.

4. Design restrictions: about the preferred solution space. Limits of the design, exclusions, and elements not covered in the design.

5. Attention points: those specifications that are relevant to the design and should be noted, but that are not requirements that have to be met, and are also not design restrictions.

\subsection{Design requirements}

Design requirements for each requirement category are provided in table form with relevant motivation for each requirement. Requirements reference indicators are noted by the following notation <Requirement\#>, using the reference key below:

- $\quad$ User requirements $=\mathrm{U}$

- $\quad$ Functional requirements $=\mathrm{F}$

- $\quad$ Design restrictions $=\mathrm{R}$

- $\quad$ Attention points $=\mathrm{A}$

- $\quad$ Boundary conditions $=\mathrm{B}$

\subsubsection{User requirements}

The following user requirements are proposed: 
U1 Requirement: The approach should consider the context of the South African SME, specifically its constraints, such as number of employees, access to resources, etc.

Motivation: The study on open innovation was conducted among South African SMEs specifically. The conclusions and recommendations, although possibly applicable to SMEs in other parts of the world, are therefore specific to South Africa. The design requirements for the approach are also intended to be focused on South Africa, and should consider the country's specific SME context. The size classification for SMEs in South Africa, for instance, is different from that in other countries such as the USA. This will have an impact on factors such as the availability of resources to be allocated to open innovation tasks, etc.

U2 Requirement: The user should be allowed flexibility to apply their own discretion when using the approach.

Motivation: The approach should not be prescriptive but rather descriptive in nature. There should be allowance for adaptability and customisation to suit the specific circumstances of the specific organisation applying the approach [24].

U3 Requirement: The approach should be user-friendly - i.e., easy to adopt, understandable, and easy to use.

Motivation: Weber [24] suggests that an approach should be user-friendly and not require specialised resources to implement it. Resource constraints within SMEs to execute the innovation process should therefore be considered. As mentioned in the survey, for example, almost 72 per cent of South African SMEs have ten or fewer employees. Specialist innovation resources are therefore highly unlikely.

U4 Requirement: The approach should be considered as a management aid for implementing open innovation within SMEs.

Motivation: 77 per cent of the survey answers were provided by owners of the organisations, and 15 per cent were from managers. The approach being designed should therefore be accessible to the management team of the SME, which often play dual roles of management and execution due to the low number of resources in the organisation.

U5 Requirement: The approach should support repeated and continued use.

Motivation: The intent of the open innovation approach is not to be a once-off application, but to be used as an embedded management approach towards innovation on a continuous basis. It should assist the SME to move from an ad hoc event (as identified in the survey for many SMEs) to a repeatable management practice within the organisation, supporting continuous innovation [29].

U6 Requirement: The approach should provide clear definitions and explanations.

Motivation: To simplify use and improve adoption of the approach, it is recommended that the approach provide clear definitions and explanations on how to implement and use the approach [24]. This should not become a barrier to use.

\subsubsection{Functional requirements}

The following functional requirements are proposed for the open innovation approach.

F1 Requirement: The approach should lead to improved open innovation within SMEs.

Motivation: The main goal of designing an open innovation approach for SMEs would be to improve the adoption and execution of open innovation in these organisations. This requirement was clear from the open innovation survey, as mentioned in Section 4.4 and Table 6. 


\begin{tabular}{|c|c|}
\hline \multirow[t]{2}{*}{ F2 } & $\begin{array}{l}\text { Requirement: The approach should cover the end-to-end lifecycle of innovation, from } \\
\text { ideation to commercialisation, for both inbound and outbound open innovation. }\end{array}$ \\
\hline & $\begin{array}{l}\text { Motivation: Open innovation can be used during any part of the innovation process } \\
{[11,12] \text {, and the approach should cater for this requirement. This was also discussed in }} \\
\text { Section 2.2. }\end{array}$ \\
\hline \multirow[t]{2}{*}{ F3 } & $\begin{array}{l}\text { Requirement: The approach should cover not only the innovation process but also the } \\
\text { organisational factors that enable innovation. }\end{array}$ \\
\hline & $\begin{array}{l}\text { Motivation: A comprehensive approach will consider the organisational factors that enable } \\
\text { innovation within the SME, since innovation is impacted by more than just the innovation } \\
\text { process. This is made clear in innovation models such as the A.T. Kearney House of } \\
\text { Innovation [27] and the Fugle innovation model [28]. }\end{array}$ \\
\hline \multirow[t]{2}{*}{$\mathrm{F} 4$} & $\begin{array}{l}\text { Requirement: The approach should provide business management method principles that } \\
\text { can be applied within open innovation. }\end{array}$ \\
\hline & $\begin{array}{l}\text { Motivation: An open innovation approach for SMEs should consider the limitations and } \\
\text { challenges SMEs face compared to larger organisations (such as limited resources and } \\
\text { organisational maturity) }[17,19] \text {, yet use management methods that are applicable to } \\
\text { SMEs to enhance the impact and effectiveness of the approach. The survey showed that } \\
\text { only } 27 \text { per cent of respondent organisations had a formal innovation process; therefore } \\
\text { management methods will enhance the business rigour with which open innovation is } \\
\text { applied within SMEs. }\end{array}$ \\
\hline F5 & $\begin{array}{l}\text { Requirement: The approach should include } \mathrm{m} \\
\text { pursued, based on the innovation requirements an }\end{array}$ \\
\hline
\end{tabular}

\begin{tabular}{|c|c|}
\hline & $\begin{array}{l}\text { Motivation: SMEs must be able to use the approach based on their own innovation } \\
\text { strategy, which will differ between organisations }[27,28] \text {. The survey also indicated } \\
\text { various innovation preferences to be pursued. }\end{array}$ \\
\hline F6 & $\begin{array}{l}\text { Requirement: The intent of the approach should be for organisations that want to apply } \\
\text { open innovation, although it should recognise that there can be varied degrees of } \\
\text { openness. }\end{array}$ \\
\hline
\end{tabular}

\begin{tabular}{|l|l|}
\cline { 2 - 3 } & Motivation: Levels of openness may vary in organisations, as described in Section 2.2. \\
\hline F7 & $\begin{array}{l}\text { Requirement: The approach should provide recommendations on the type of open } \\
\text { innovation selection, in order to increase the chances of open innovation success. }\end{array}$ \\
\hline
\end{tabular}

\begin{tabular}{|l|l|}
\hline \multirow{2}{*}{ F8 } & $\begin{array}{l}\text { Motivation: The open innovation survey study showed that SMEs are planning to use } \\
\text { various open innovation types for the development of new innovations. An open innovation } \\
\text { approach should therefore be able to cater for these various open innovation types (Figure } \\
\text { 6), since their application may be different. } \\
\text { Requirement: The approach should be useful for various sectors and innovation types. }\end{array}$ \\
\cline { 2 - 3 } & $\begin{array}{l}\text { Motivation: SMEs that use the approach will no doubt have various levels of business and } \\
\text { innovation maturity and will be from various business sectors, as was also clear from the } \\
\text { survey results presented in Section } 4.1 \text {. }\end{array}$ \\
\hline F9 & $\begin{array}{l}\text { Requirement: The approach should include or recommend tools and aids to assist with } \\
\text { executing open innovation. }\end{array}$ \\
\cline { 2 - 3 } & $\begin{array}{l}\text { Motivation: Although not meant to be an exhaustive manual, the open innovation } \\
\text { approach should provide tools and techniques to accommodate these varied organisations } \\
{[24], \text { and assist users to implement a structured open innovation process. }}\end{array}$ \\
\hline
\end{tabular}


F10 Requirement: The approach should consider the innovation maturity level of the organisation.

Motivation: The survey study highlighted the varied degrees of innovation maturity across the surveyed organisations, with only 27 per cent of organisations having a formal innovation process, and 40 per cent being slightly or strongly comfortable with pursuing open innovation themselves.

\subsubsection{Design restrictions and attention points}

Design restrictions should provide limits to the design. If restrictions are too severe, they can impact on the usefulness of the approach by making it too narrow. If the design is too broad, however, it could have the reverse effect of becoming overly generic and losing its applicability. The following design restrictions and attention points are proposed:

\begin{tabular}{|c|c|}
\hline \multirow[t]{2}{*}{$\mathrm{R} 1$} & $\begin{array}{l}\text { Requirement: The approach is not meant to include an exhaustive set of tools and } \\
\text { methods available for open innovation, but should be comprehensive enough to provide } \\
\text { sufficient relevant options for SMEs. }\end{array}$ \\
\hline & $\begin{array}{l}\text { Motivation: No single method can be all things for all situations. The open innovation } \\
\text { method should be comprehensive, but it is not expected to contain every possible open } \\
\text { innovation tool in existence. Having too broad a coverage could make the approach } \\
\text { cumbersome and clumsy, reducing its effectiveness and increasing resistance to adopting } \\
\text { it within the organisation [24]. }\end{array}$ \\
\hline \multirow[t]{2}{*}{$\mathrm{R} 2$} & $\begin{array}{l}\text { Requirement: The approach is intended for SMEs, even though some principles, tools, and } \\
\text { methods may be applicable to larger organisations. }\end{array}$ \\
\hline & $\begin{array}{l}\text { Motivation: As previously stated, the approach should be for the intended use of SMEs. } \\
\text { Some of its tools may be applicable to larger organisations, but it should remain focused } \\
\text { on being relevant to SMEs. Both large organisations and SMEs can, for instance, use a } \\
\text { method such as IP in-licensing; but due to the nature of the organisations, how they do } \\
\text { this will be different }[19,23] \text {. }\end{array}$ \\
\hline \multirow[t]{2}{*}{ R3 } & $\begin{array}{l}\text { Requirement: The approach is not a legal or legislative guide, and input required for such } \\
\text { items (e.g., IP management) should be obtained from specialists within those fields. }\end{array}$ \\
\hline & $\begin{array}{l}\text { Motivation: IP management is an important factor to consider in open innovation [30], } \\
\text { even though participants in the survey gave this issue low attention. Legal and legislative } \\
\text { interpretations can be complex, however, depending on the situation of application. It is } \\
\text { therefore recommended that the approach cover IP management as a consideration, but } \\
\text { not aim to provide legal interpretations or advice [24]. }\end{array}$ \\
\hline \multirow[t]{2}{*}{$\mathrm{R} 4$} & $\begin{array}{l}\text { Requirement: The approach does not guarantee open innovation success due to the } \\
\text { multitude of factors that could influence such an outcome. However, it does provide } \\
\text { principles based on theory and practice to increase chances of success when applied. }\end{array}$ \\
\hline & $\begin{array}{l}\text { Motivation: It would be naïve to think that the innovation approach will guarantee open } \\
\text { innovation success in an organisation. Open innovation is challenging to implement, and } \\
\text { multiple other factors could impact on the success of open innovation and/or business } \\
\text { success [23,31]. The approach should provide a guide based on the best practice } \\
\text { principles for implementing open innovation in organisations, in order to improve the } \\
\text { chances of success. }\end{array}$ \\
\hline $\mathrm{A} 1$ & $\begin{array}{l}\text { Requirement: Some items to be included in the approach will be discretionary and } \\
\text { dependent on factors inherent to the organisation, such as its set-up, size, and strategy. } \\
\text { Decisions about how or whether at all to apply these will therefore differ between } \\
\text { organisations. Examples of these include IP agreements and technology use. }\end{array}$ \\
\hline
\end{tabular}




\begin{tabular}{|l|l|}
\hline A1 & $\begin{array}{l}\text { Motivation: Functional requirements 4, 5, and 8, as well as design restriction 3, mention } \\
\text { the variability within SMEs. Organisations have different organisational elements that can } \\
\text { impact on innovation (such as a formal innovation process, organisational strategy, } \\
\text { available resources, and market dominance) and will therefore require discretion from } \\
\text { management on how the innovation approach will be implemented within the } \\
\text { organisation. Since the approach is descriptive in nature, it allows for flexibility in its } \\
\text { application. }\end{array}$ \\
\hline A2 & $\begin{array}{l}\text { Requirement: It is acknowledged that open innovation in SMEs as a formal discipline is } \\
\text { still very new, and that the approach to be developed will be based on emerging findings } \\
\text { from larger organisations and SMEs. The approach should be seen as a reflection of early } \\
\text { best practice within an evolving field of knowledge. }\end{array}$ \\
\cline { 2 - 3 } & $\begin{array}{l}\text { Motivation: Academic research on open innovation, and specifically open innovation } \\
\text { within SMEs, is still relatively undeveloped [16,17,18]. The open innovation approach } \\
\text { being designed needs, therefore, to draw upon a small pool of available expert content, } \\
\text { and would also need to deduce findings from research done within large organisations, } \\
\text { which is more readily available than research into open innovation in SMEs. }\end{array}$ \\
\hline
\end{tabular}

\subsubsection{Boundary conditions}

The boundary conditions provide rules of use. The following boundary conditions are proposed.

\begin{tabular}{|l|l|}
\hline B1 & \begin{tabular}{l} 
Requirement: The approach should be used in a legal and ethical way by the SME. \\
\cline { 2 - 2 }
\end{tabular} \\
\hline B2 & $\begin{array}{l}\text { Motivation: The authors cannot control the use and possible exploitation of the open } \\
\text { innovation approach in practice. It is therefore important to define the reasonably } \\
\text { assumed boundaries of application [24]. It is assumed, for instance, that the open } \\
\text { innovation approach will be applied in a legal and ethical way, adhering to corporate } \\
\text { governance and other relevant restrictions. }\end{array}$ \\
\hline & $\begin{array}{l}\text { Requirement: The approach should not be used to negatively exploit other parties } \\
\text { involved in the open innovation process. }\end{array}$ \\
\hline & $\begin{array}{l}\text { Motivation: Due to the nature of open innovation, parties involved in the sharing of ideas, } \\
\text { knowledge, and technology can easily be exploited by interacting parties [30]. Especially } \\
\text { when there is a power imbalance, the smaller of the parties could be at a disadvantage } \\
\text { [19,31]. }\end{array}$ \\
\hline B3 & $\begin{array}{l}\text { Requirement: The open innovation approach should promote value for all parties involved } \\
\text { and assist in establishing trust. }\end{array}$ \\
\hline & $\begin{array}{l}\text { Motivation: The intent of the open innovation approach should be to obtain mutual } \\
\text { appropriate value for all parties involved in the innovation process [1,30]. }\end{array}$ \\
\hline
\end{tabular}

\section{CONCLUSION AND RECOMMENDATIONS}

Although the survey provides a good indication of the open innovation landscape within SMEs in South Africa, it is suggested that a more exhaustive study be conducted that could also be used to measure a shift in results over time, as open innovation becomes a more mainstream innovation method. A comparative study can also be done to test the adoption rate of open innovation in companies that use networking platforms versus those that do not participate in these social networks. The survey presented in this article adds to the body of knowledge on SMEs in South Africa, and specifically on the use of open innovation in these organisations. 
The design requirements proposed in this article can be used as input into the development of an open innovation approach for SMEs. The need for such an approach is evident from the survey results, and they confirm similar requirements stated elsewhere in the academic literature on open innovation in SMEs. Further work needs to be done to develop a model that focuses on the framework and content requirements of such an approach. This article aims to provide a first step in achieving such a goal, providing the design requirements on which the approach could be built. A comprehensive open innovation approach will better equip SMEs to adopt open innovation as a decisive innovation strategy within their organisations, thereby enhancing their innovation capability.

\section{REFERENCES}

[1] Chesbrough, H.W. 2003. Open innovation: The new imperative for creating and profiting from technology. Boston: Harvard Business School Press.

[2] Lindegaard, S. 2011. Making open innovation work. CreateSpace, North Charleston, SC.

[3] OECD. 2008. Open innovation in global networks. Organisation for Economic Co-Operation and Development, Policy Brief, November 2008.

[4] Krause, W., Schutte, C.S.L. \& Du Preez, N. 2012. An exploratory study on preferred open innovation types and partners in South African SMEs. Conference Proceedings, Industrial Engineering and Engineering Management Conference, Hong Kong.

[5] Nonaka, I., Konno, N. \& Toyama, R. 2001. Emergence of "BA". In: Knowledge emergence: Social, technical, and evolutionary dimensions of knowledge creation, pp. 13-29.

[6] Schutte, C.S.L. \& Du Preez, N. 2010. A comparative study about the formal design life cycle of the integrated knowledge network to support innovation. Conference Proceedings, International Conference on Competitive Manufacturing, Stellenbosch, South Africa.

[7] Krause, W., Schutte, C.S.L. \& Du Preez, N. 2012. Open innovation in South African small and medium-sized enterprises. CIE42 Conference Proceedings, Cape Town, South Africa.

[8] Foss, N.J., Laursen, K. \& Pedersen, T. 2005. Organizing to gain from user interaction: The role of organizational practices for absorptive and innovative capacities. Copenhagen Business School.

[9] Drucker, P. 1985. Innovation and entrepreneurship: Practice and principles. London: Heinemann.

[10] Enkel, E. \& Gassmann, O. 2010. Creative imitation: Exploring the case of cross-industry innovation. R\&D Management, 40 (3), pp. 256-270.

[11] Chesbrough, H.W. \& Eichenholz, J.M. 2013. Open innovation in photonics: The case for sharing and harvesting innovations in photonics. SPIE Professional, January 2013.

[12] Gassmann, O. \& Enkel, E. 2004. Towards a theory of open innovation: Three core process archetypes. Proceedings of the R\&D Management Conference.

[13] Fatoki, O. \& Odeyemi, A. 2010. Which new small and medium enterprises in South Africa have access to bank credit? International Journal of Business and Management, 5 (10), pp. 128-136.

[14] International Institute for Sustainable Development. 2004. Issue briefing note: Small and medium-sized enterprises.

[15] Adcorp Employment Index. 2012. Retrieved from www.adcorp.co.za. Accessed in April 2012.

[16] Chesbrough, H. 2010. How smaller companies can benefit from open innovation. Economy, Culture \& History JAPAN SPOTLIGHT Bimonthly, Japan Economic Foundation.

[17] Bianchi, M., Campodall'Orto, S., Frattini, F. \& Vercesi, P. 2010. Enabling open innovation in small and medium-sized enterprises: How to find alternative applications for your technologies. R\&D Management, 40 (4), pp. 414-431.

[18] Gassmann, O., Enkel, E. \& Chesbrough, H. 2010. The future of open innovation. R\&D Management, 40 (3), pp. 213-221.

[19] Brunswicker, S. 2009. The networked SME - Taking a closer look into open and collaborative innovation in European SMEs. Open Innovation Speaker Series, Haas School Of Business, UC Berkeley.

[20] Jin, E.M., Girvan, M. \& Newman, M.E.J. 2001. The structure of growing social networks. Physical Review E, 64 (4).

[21] Clinton, L. \& Whisnant. R. 2014. 20 business model innovations for sustainability. SustainAbility Inc.

[22] Lichtenthaler, U. \& Lichtenthaler, E. 2009. A capability-based framework for open innovation: Complementing absorptive capacity. Journal of Management Studies, 46 (8), pp. 1315-1338.

[23] Chesbrough, H. \& Brunswicker, S. 2013. Managing open innovation in large firms. Fraunhofer Verlag.

[24] Weber, M. 2011. Customer co-creation in innovations: A protocol for innovating with end users. Doctoral thesis, Technische Universiteit Eindhoven. 
[25] Brockmöller, A.A.C. 2008. Knowledge sharing in expert-apprentice relations: Design of a protocol. Doctoral thesis, Rijksuniversiteit Groningen.

[26] Van Aken, J. E., Berends, H. \& Van der Bij, H. 2007. Problem solving in organizations. Cambridge: Cambridge University Press.

[27] Innovation Management. 2012. How to deal with innovation management when you are small? Retrieved from http://www.innovationmanagement.se/2012/12/19/how-to-deal-withinnovation-management-when-you-are-small/. Accessed in October 2013.

[28] Du Preez, N.D. \& Louw, L. 2008. a framework for managing the innovation process. Conference Proceedings, PICMET '08.

[29] Carpinetti, L.C.R., Gerolamo, M.C. \& Galdámez, E.V.C. 2007. Continuous innovation and performance management of SME clusters. Creativity and Innovation Management Journal, 16(4), pp. 376-385.

[30] Bogers, M., Bekkers, R. \& Granstrand, O. 2012. Open innovation at firms and public administrations: Technologies for value creation. In: Heredero, C.P. \& López, D. (eds). Hershey, PA: IGI Global, pp. 37-58.

[31] Van de Vrande, V., De Jong, J.P.J., Vanhaverbeke, W. \& De Rochemont, M. 2008. Open innovation in SMEs: Trends, motives and management challenge. Scientific Analysis of Entrepreneurship and SMEs (SCALES). 